\title{
COMPARATIVE ASPECTS OF GASTROINTESTINAL PHOSPHORUS METABOLISM
}

\author{
GERHARD BREVES ${ }^{1}$ AND BERND SCHRÖDER ${ }^{2}$ \\ ${ }^{1}$ Department of Veterinary Physiology, ${ }^{2}$ Department of Parasitology, Justus Liebig \\ University, Giessen, Germany
}

\section{CONTENTS}

INTRODUCTION . . . . . . . . . . . . . . . . . . . . . 125

ENDOGENOUS SECRETION INTO THE GASTROINTESTINAL TRACT . 126

SITES AND MECHANISMS OF GASTROINTESTINAL P ABSORPTION . 126

NON-RUMINANTS .

Small intestines . . . . . . . . . . . . . . . . . . . . . . . . . . . . . 126

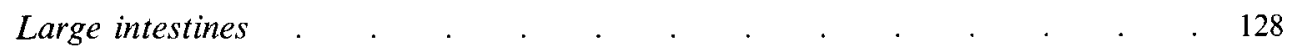

RUMINANTS .

Forestomach and abomasum . . . . . . . . . . . . . . . . . . . . . 129

Small intestines . . . . . . . . . . . . . . . . 129

Large intestines . . . . . . . . . . . . . . . . . . . . 130

HORMONAL REGULATION OF P HOMEOSTASIS . . . . . . 130

CONTROL OF EPITHELIAL Pi TRANSPORT . . . . . . . . . . . 131

INTERACTIONS BETWEEN P AND Ca HOMEOSTASIS . . . . . . . . . 131

DIETARY P DEFICIENCY IN RUMINANTS: EFFECTS ON MICROBIAL

METABOLISM IN THE GASTROINTESTINAL TRACT . . . . . 133

CONCLUSIONS . . . . . . . . . . . . . . . . . . . . . . . 134

REFERENCES . . . . . . . . . . . . . . . . . 135

\section{INTRODUCTION}

The physiological role of phosphorus as an essential component of many organic and inorganic compounds is well documented. Whereas $80 \%$ of total body $\mathrm{P}$ is localized within the bone, mainly as hydroxyapatites with varying calcium: $\mathrm{P}$ ratio, the remaining $20 \%$ in cells, cell membranes and body fluids is a major constituent of different organic compounds and enables the regeneration of energy-supplying substances and contributes as an additional buffer system.

The basic mechanisms of gastrointestinal $\mathrm{P}$ metabolism differ substantially when ruminant and non-ruminant species are compared. In ruminants large amounts of inorganic $\mathbf{P}\left(\mathrm{P}_{\mathrm{i}}\right)$ are secreted into the gastrointestinal tract by the salivary glands and this endogenous secretion normally is well balanced by net $P_{i}$ absorption from the upper small intestines. Neither the transport mechanisms involved nor their regulation is clearly identified. In contrast to single-stomach animals renal $\mathbf{P}_{\mathbf{i}}$ excretion is low in ruminants and, thus, does not contribute significantly to the overall regulation of $\mathbf{P}_{i}$ homeostasis. However, individual animals have been reported which are characterized by a significant renal $P_{i}$ excretion and, thus, behave like single-stomach animals. The reasons for this are unknown. 
It is the aim of the present review to discuss the major differences in gastrointestinal $\mathbf{P}_{i}$ transport mechanisms and their hormonal regulation between ruminant and non-ruminant species. In addition, the effects of dietary $\mathrm{P}$ deficiency on microbial metabolism in the rumen are considered.

\section{ENDOGENOUS SECRETION INTO THE GASTROINTESTINAL TRACT}

In ruminants the salivary glands are the major site for endogenous $\mathrm{P}_{\mathrm{i}}$ secretion into the gastrointestinal tract. The daily secretion rate between 5 and $10 \mathrm{~g} \mathbf{P}_{\mathrm{i}}$ in sheep and between 30 and $60 \mathrm{~g} \mathrm{P}_{\mathrm{i}}$ in cows (Breves et al. 1987; Reinhardt et al. 1988; Scott, 1988) is achieved by both the high salivary flow-rate and the ability of the salivary glands to concentrate $P_{i}$ in comparison with plasma $\mathrm{P}_{\mathrm{i}}$. However, it has to be considered that the concentration ratio between plasma and saliva from the individual glands may differ substantially. Concentrations between 12.5 and $32 \mathrm{~mm}$ were determined in parotid saliva of conscious sheep whereas in the submaxillary glands the $P_{i}$ concentration ranged between 1 and $5 \mathrm{~mm}$ (Kay, 1960). The $P_{i}$ concentration in parotid saliva is mainly determined by the plasma $P_{i}$ concentration. Scott \& Beastall (1978) and Mañas-Almendros et al. (1982) found a linear increase in parotid saliva $P_{i}$ when the plasma $P_{i}$ concentrations were increased to 4-5 mM by intravenous $P_{i}$ infusions. Under these conditions the concentration ratio between saliva and plasma $P_{i}$ varied between 12:1 and 16:1. Although it could be demonstrated by a micropuncture study that the end-pieces of the parotid gland are the major site for $P_{i}$ secretion (Compton et al. 1980), the transport mechanisms which are involved in this process are still unknown. Recently, Shirazi-Beechey et al. (1991) studied the $P_{i}$ uptake across basolateral membrane (BLM) vesicles (BLMV) obtained from sheep parotid epithelial cells and they postulated the presence of a $\mathrm{Na}^{+}$-dependent electrogenic $\mathrm{P}_{\mathrm{i}}$ transport system. So far, however, no information is available on transport processes across the apical membrane. Controversy still exists about whether $\mathrm{P}_{\mathrm{i}}$ secretion is regulated by parathyroid hormone (PTH) or 1,25-dihydroxycholecalciferol $\left(1,25-(\mathrm{OH})_{2} \mathrm{D}_{3}\right.$, calcitriol, vitamin D-hormone; Compton et al. 1980; Mañas-Almendros et al. 1982; Wright et al. 1984).

In single-stomach species salivary $P_{i}$ concentrations are substantially lower (Nielsen \& Petersen, 1970; Coroneo et al. 1981; Young \& Schneyer, 1981) and, since the daily salivary flow-rates are also lower, salivary $P_{i}$ secretion only represents a small proportion of total $P_{i}$ in the intestinal lumen which is available for absorption.

Small amounts of $P_{i}$ are secreted with gastric and pancreatic juice, bile and intestinal fluid. There is no evidence that these secretions differ significantly between ruminant and non-ruminant species and their overall contribution to gastrointestinal $\mathbf{P}_{\mathbf{i}}$ turnover is of minor importance (Wilkinson, 1976; Scott, 1988).

\section{SITES AND MECHANISMS OF GASTROINTESTINAL i $_{i}$ ABSORPTION}

NON-RUMINANTS

\section{Small intestines}

It is generally accepted that the small intestines are the major site for $P_{i}$ absorption in single-stomach species and that this transport is stimulated by vitamin $D$ (Harrison \& Harrison, 1961; Wasserman \& Taylor, 1976; Radde et al. 1980; Jungbluth \& Binswanger, 1989). The transepithelial $P_{i}$ transport consists of both an active saturable and a passive 
non-saturable component (Danisi \& Straub, 1980; Hildmann et al. 1982; Drüeke \& Lacour, 1983; Lee et al. 1986a).

The active vitamin D-stimulated component which is not coupled to the transcellular Ca transport, depends on the presence of sodium in the lumen compartment (Fuchs \& Peterlik, 1980; Peterlik et al. 1981; Wasserman, 1988). Controversy still exists as to what extent $P_{i}$ may be transported paracellularly. However, since the active transport is readily saturable, passive absorption may predominate at high lumen $\mathrm{P}_{\mathrm{i}}$ concentrations (Neer, 1979; Reinhardt et al. 1988).

Quantitatively $\mathrm{P}_{\mathrm{i}}$ absorption differs along the small intestines (Walling, 1977; Danisi \& Straub, 1980; Danisi et al. 1980; Lee et al. 1980). From in vivo studies in rats McHardy \& Parsons (1956) concluded that $\mathrm{P}_{\mathrm{i}}$ absorption was higher in the jejunum compared with the ileum, and Harrison \& Harrison (1961) investigated the effects of vitamin D by applying the everted-sac technique and found the highest transport in the jejunum with decreasing rates of transfer in the duodenum and ileum.

In order to differentiate between passive and active transport processes more recent studies were carried out with porcine and rat small intestines using the in vitro Ussingchamber technique (Radde et al. 1980; Favus, 1985; Jungbluth \& Binswanger, 1989). Since these experiments were done in the absence of any chemical or electrical gradients significant transepithelial net fluxes required an active mechanism. In porcine tissues net $\mathbf{P}_{i}$ absorption predominantly occurred in the jejunum and to a lower extent in the duodenum $\left(160 \mathrm{nmol} / \mathrm{cm}^{2}\right.$ per $\mathrm{h} v .40 \mathrm{nmol} / \mathrm{cm}^{2}$ per h). It was negligible in the ileum. Net $P_{i}$ fluxes obtained from rat small intestines confirmed the jejunum to be the major site for active $\mathrm{P}_{\mathrm{i}}$ absorption (Walling, 1977; Jungbluth \& Binswanger, 1989). However, the flux-rates were substantially lower in control animals $\left(8 \mathrm{nmol} / \mathrm{cm}^{2} \mathrm{per} \mathrm{h}\right)$ as compared with P-depleted rats $\left(33 \mathrm{nmol} / \mathrm{cm}^{2}\right.$ per h).

In another series of experiments with small intestines from vitamin D-deficient rats it was shown that in the absence of significant plasma $1,25-(\mathrm{OH})_{2} \mathrm{D}_{3}$ levels jejunal net $\mathrm{P}_{i}$ absorption persists at a level of $25 \mathrm{nmol} / \mathrm{cm}^{2}$ per $\mathrm{h}$ and increased in response to $1,25-$ $(\mathrm{OH})_{2} \mathrm{D}_{3}$ repletion to about $40 \mathrm{nmol} / \mathrm{cm}^{2}$ per h (Walling, 1977). Unlike the jejunum, net $P_{i}$ secretion was present in the duodenum and ileum during vitamin $\mathrm{D}$ deficiency. However, 1,25- $(\mathrm{OH})_{2} \mathrm{D}_{3}$ administration converted the duodenal net $\mathrm{P}_{\mathrm{i}}$ secretion to a small but significant absorption and reduced, but did not abolish, net $P_{i}$ secretion in the ileum. In contrast to the findings with pig and rat small intestines, in rabbit small intestines the active $\mathrm{P}_{i}$ transport was highest in the duodenum. Thus, species differences have also to be considered (Danisi \& Straub, 1980). It should be stated, however, that in vitro studies may help to characterize transport mechanisms but they do not allow any conclusive evidence on the major absorptive sites under in vivo conditions.

Despite obvious species differences and varying nutritional and hormonal effects which may modulate small intestinal $P_{i}$ absorption it may be concluded from the present findings that in non-ruminants the proximal parts of the small intestines are predominant for active $\mathrm{P}_{\mathrm{i}}$ absorption in comparison with the distal regions. In addition, it is generally accepted that ions, such as $\mathrm{Ca}^{2+}$ or $\mathrm{P}_{\mathrm{i}}$, can only be absorbed in the soluble form. Since the intralumen $\mathrm{pH}$ increases along the small intestines the solubility and, thus, the absorption of $\mathrm{P}_{\mathrm{i}}$ could be affected by these changes in a similar way as it has been shown for $\mathrm{Ca}^{2+}$ in man (Sheikh et al. 1990).

Cellular $\mathrm{P}_{\mathrm{i}}$ transport consists of at least three steps (Murer \& Hildmann, 1981; Karsenty et al. 1985 a; Danisi et al. 1988; Shirazi-Beechey et al. 1988): (1) $\mathbf{P}_{\mathrm{i}}$ entry across the lumen brush-border membrane (BBM) into the enterocyte; (2) intracellular $\mathrm{P}_{\mathrm{i}}$ transport from the lumen to the basolateral side of the cell and (3) $\mathrm{P}_{\mathrm{i}}$ extrusion across the BLM.

Conclusive evidence for a secondary active $\mathrm{Na}^{+}-\mathrm{P}_{\mathrm{i}}$ cotransport system across the BBM 
of rabbit and rat small intestines has been shown by several laboratories, using BBM vesicles (BBMV) (Berner et al. 1976; Murer \& Hildmann, 1981; Quamme, 1985; Danisi et al. 1988; Shirazi-Beechey et al. 1988). The maximum velocity $\left(V_{\max }\right)$ of this symporter is increased by vitamin D-hormone and $\mathrm{P}$ deficiency with little or no effect on the Michaelis constant $\left(K_{m}\right)$ (Peterlik \& Wasserman, 1978; Quamme, 1985; Caverzasio et al. 1987; Danisi et al. 1988). It has not yet been clearly elucidated whether the carrier preferentially accepts either the monovalent or the divalent $P_{i}$ and whether the carrier induces a net charge transfer across the lumen membrane (Cross et al. 1990).

Evidence for a $\mathrm{Na}^{+}$-independent diffusional mechanism for cellular $\mathrm{P}_{\mathrm{i}}$ uptake was presented by Danisi \& Straub (1980) and Karsenty et al. (1985a) from studies in rabbits and rats. The molecular structure of the $\mathrm{Na}^{+}-\mathrm{P}_{\mathrm{i}}$ symporter still remains to be identified. Possible candidates are the polypeptides with molecular weights between 130 and $155 \mathrm{kD}$ found in different studies with rabbit BBMV (Debiec \& Lorenc, 1988; Peerce, 1988, 1989). Using an antibody technique, Shirazi-Beechey et al. (1988) have shown that guinea-pig antibodies to rabbit $\mathrm{BBMV}$ could inhibit the $\mathrm{Na}^{+}$-dependent $\mathrm{P}_{\mathrm{i}}$-transport. By this technique another suitable tool might be provided for further identifying and characterizing the lumen $P_{i}$ carrier protein.

There is only a small amount of information on the mechanisms of intracellular $P_{i}$ transport. Measurements of intracellular $P_{i}$ are complicated by metabolic conversion and/or intracellular compartmentalization of $P_{i}$. There is some evidence from compartmental analysis of the specific activity of transported $P_{i}$ that the ion migrates from the lumen to the contralumen pole of the enterocyte in a discrete transport pool which is not readily exchanged with intracellular $P_{i}$ (Kowarski \& Schachter, 1969; Peterlik \& Wasserman, 1978).

The intracellular migration of $P_{i}$ can be blocked by adding cytochalasin $B$ in concentrations which are sufficient to disrupt the microfilament system of absorptive cells (Fuchs \& Peterlik, 1979). A second possibility which has received experimental support considers the steroid-like, receptor-mediated action of $1,25-(\mathrm{OH})_{2} \mathrm{D}_{3}$, triggering the transcription of specific genes that code for carrier proteins (DeLuca, 1988). The 1,25$(\mathrm{OH})_{2} \mathrm{D}_{3}$-stimulated $\mathrm{P}_{\mathrm{i}}$ transport can be blocked by inhibitors of RNA and protein synthesis such as actinomycin D, a-amanitin and cycloheximide (Peterlik et al. 1981). However, the existence of specific and vitamin D-dependent cytosolic $P_{i}$-carrier proteins still has to be proved. Recently, specific phosphate transport proteins were determined in bacterial cells (Luecke \& Quiocho, 1990).

The mechanisms of $P_{i}$ extrusion across the BLM are not yet fully understood. Studies of rat jejunum suggest that it involves a $\mathrm{Na}^{+}$-independent carrier-mediated mechanism which is driven by the electrochemical gradient (Danisi et al. 1984; Quamme, 1985). However, the studies of Ghishan et al. (1987) suggest the presence of a high-affinity $\mathrm{Na}^{+}$-dependent $\mathrm{P}_{\mathrm{i}}$ carrier in BLMV prepared from the small intestines of rats. In addition, a similar mechanism has been detected in human small intestinal BLMV (Kikuchi \& Ghishan, 1987).

\section{Large intestines}

The hind-gut is of minor importance for the overall $P_{i}$ absorption along the gastrointestinal tract (Cramer, 1972). From studies in pigs no $\mathrm{P}_{\mathrm{i}}$ absorption from the large intestines could be detected (Guéguen et al.1968; Partridge et al. 1986). However, this may be different when pigs are kept on high-P diets (Drochner, 1984; Den Hartog et al. 1985). In vitro experiments on colonic $P_{i}$ transport mechanisms in rats have shown that $P_{i}$ may be transported by passive diffusion with no significant effects of vitamin $\mathrm{D}$ (Lee et al. 1980). 


\section{RUMINANTS}

\section{Forestomachs and abomasum}

Different experimental techniques have been adopted to study the extent to which $P_{i}$ is absorbed up to the proximal duodenum and which mechanisms are involved. Measurements on concentration differences between rumen fluid and venous plasma or between arterial and venous blood draining the reticulo-rumen did not show any significant phosphate transport (Parthasarathy, 1952; Parthasarathy et al. 1952; Yano et al. 1978). The permeability of the rumen epithelium for phosphate in both directions could be demonstrated by infusing ${ }^{32} \mathrm{P}$ either intraruminally (Scarisbrick \& Ewer, 1951; Parthasarathy et al. 1952; Wright, 1955; Pfeffer, 1968) or intravenously (Parthasarathy et al. 1952; Smith et al. 1955). From these studies, however, it was concluded that the rumen wall is not a major site for net $\mathbf{P}_{\mathrm{i}}$ absorption. This does not agree with results from recent in vivo studies in sheep measuring $\mathrm{P}_{\mathrm{i}}$ absorption by applying the washed and temporarily isolated rumen technique which have shown a close positive linear relationship between rumen $\mathrm{P}_{\mathrm{i}}$ concentration and net $\mathrm{P}_{\mathrm{i}}$ disappearance (Breves et al. 1988; Beardsworth et al. 1989). The slope of this regression significantly increased when the experiments were done in P-depleted sheep with plasma $P_{1}$ concentrations of less than $1 \mathrm{~mm}$. This indicates that rumen $\mathrm{P}_{\mathrm{i}}$ transport may be modulated by the transepithelial chemical gradient. Since the normal transmural electrical potential difference also favours passive $\mathbf{P}_{i}$ transport it was postulated that $\mathbf{P}_{\mathrm{i}}$ passes the rumen wall by passive diffusion. This could be confirmed by in vitro measurements in Ussing chambers. When the unidirectional flux rates were measured under short-circuit-current conditions no significant net flux could be determined which proved the absence of an active transport system (Breves et al. 1988). The involvement of an active transport system had been suggested in an earlier paper based on tissues obtained from a small number of young sheep (Breves et al. 1986). Since the unidirectional $\mathbf{P}_{\mathrm{i}}$ fluxes could either be enhanced or reduced respectively by setting the serosal side to a positive $(+25 \mathrm{mV})$ or negative $(-25 \mathrm{mV})$ potential, it was concluded that $\mathrm{P}_{\mathrm{i}}$ is at least partly transported in the ionized form (Breves et al. 1988). Further components of rumen $\mathrm{P}_{\mathrm{i}}$ transport have not yet been identified. It should be noted, however, that neither the in vivo nor the in vitro measurements may be used to give a reliable estimate of the quantitative importance of the rumen for overall gastrointestinal $\mathrm{P}_{\mathrm{i}}$ absorption.

The omasal wall is characterized by similar transport properties to the rumen (Höller et al. 1988a) which confirms in vivo experiments in ruminating calves (Edrise \& Smith, 1986). In these experiments between 10 and $40 \%$ of $\mathrm{P}$ entering the omasum were absorbed. In contrast, only a low $\mathrm{P}$ absorption of less than $0.5 \mathrm{~mm} / \mathrm{h}$ was calculated from in vivo studies in sheep (Engelhardt \& Hauffe, 1975). A few experiments have been carried out to study $P_{i}$ absorption across the abomasal wall and it was found that only small amounts of $P$ were either secreted into or absorbed from the abomasum (Smith et al. 1955; Poppi \& Ternouth, 1979; Sklan \& Hurwitz, 1985). In vitro studies have not yet been performed to characterize the transport mechanisms.

\section{Small intestines}

It has clearly been shown that as in single-stomach animals, the small intestines are the major site for net $\mathrm{P}_{\mathrm{i}}$ absorption in ruminants (Bruce et al. 1966/67; Pfeffer et al. 1970; Grace et al. 1974). In contrast to single-stomach animals, however, little is known about the sites, mechanisms and regulation of intestinal $\mathrm{P}_{\mathrm{i}}$ absorption. Care et al. (1980) perfused jejunal Thiry-Vella-loops with increasing $P_{i}$ concentrations and postulated a carriermediated facilitated diffusion. Whereas Care et al. (1980) increased the $P_{i}$ concentration to $20 \mathrm{~mm}$ and, thus, maintained a physiological concentration range, Scott et al. (1984) 
perfused the duodenum and jejunum with $\mathrm{P}_{\mathrm{i}}$ concentration up to $50 \mathrm{~mm}$. From the relationship between $P_{i}$ concentration and $P_{i}$ absorption they also suggested the involvement of a carrier.

In growing lambs the highest rate of absorption was determined in the mid jejunum, and this could be inhibited by galactose or glucose, indicating a competitive mechanism between $P_{i}$ and sugars (Scharrer, 1985). Thus, the specificity of the active $P_{i}$ transport mechanism in lambs is possibly less than in rabbits (Hildmann et al. 1982). Recently, $\mathrm{P}_{\mathrm{i}}$ uptake by BBMV prepared from enterocytes of the upper small intestine was measured (Shirazi-Beechey et al. 1991). An electroneutral $P_{i}$ uptake was found which depended on the $\mathrm{pH}$ gradient between the buffer solutions inside and outside the vesicles. A similar transport system has already been discussed for renal cells and this effect might reflect either changes of the transport properties or $\mathrm{pH}$-dependent changes of the ratio between the mono- and divalent phosphate molecules (Sacktor \& Cheng, 1981). The transport capacity was increased during development of the rumen (Shirazi-Beechey et al. 1989) and by P depletion (Shirazi-Beechey et al. 1991) which might have been due to induction of new transporters. A $\mathrm{Na}^{+}-\mathrm{P}_{1}$ cotransport system could be detected in the ileum only and this could be stimulated by $1,25-(\mathrm{OH})_{2} \mathrm{D}_{3}$ (Schneider et al. 1987).

\section{Large intestines}

Experimental findings on $\mathrm{P}$ net absorption from the hind-gut vary over a wide range. When sheep were kept on a daily $\mathrm{P}$ intake between 1.0 and $4.1 \mathrm{~g} \mathrm{P}$, net absorption ranged between 2 and $30 \%$ of the P amount entering the hind-gut (Bruce et al. 1966/67; Pfeffer et al. 1970; Grace, 1972; Grace et al. 1974; Ben-Ghedalia et al. 1975, 1982; Greene et al. 1983; Breves et al. .1985; Théwis \& François, 1985; Wylie et al. 1985). This could be changed to $\mathrm{P}$ net secretion with higher dietary $\mathrm{P}$ intakes (Ben-Ghedalia et al. 1975; Breves et al. 1985).

It is still unclear whether these small amounts of $P$ are transported by active and/or passive transport processes. When the colon and rectum of sheep were continuously perfused with different buffer solutions containing $P_{i}$ concentrations between 2.0 and $6.5 \mathrm{~mm}$, the measured $P_{1}$ absorption was equivalent to the theoretical absorption by applying the Nernst equation suggesting a simple diffusion as transport mechanism. At phosphate concentrations between $0 \cdot 2$ and $2.0 \mathrm{~mm}$ the measured $\mathrm{P}_{\mathrm{i}}$ absorption exceeded the calculated which might be an indicator for an active transport mechanism (Höller et al. 1988 b). However, so far no detailed studies have been performed to characterize the mechanisms possibly involved in phosphate transport in the large intestines.

\section{HORMONAL REGULATION OF P HOMEOSTASIS}

From experiments with non-ruminant species it is well known that the regulation of $\mathrm{P}$ homeostasis is mainly dependent on both renal $P_{i}$ excretion and intestinal absorption (Wilkinson, 1976; Neer, 1979; Audran \& Kumar, 1985). If an animal is kept on a diet containing less $P$ than it requires, the proportion of dietary $P$ actually absorbed is increased and concomitantly renal $\mathrm{P}_{\mathrm{i}}$ reabsorption from the tubuli is also increased in order to minimize urinary $\mathbf{P}_{\mathrm{i}}$ output (Audran \& Kumar, 1985; Portale et al. 1989; Mulroney \& Haramati, 1990). In contrast to these species, ruminants do not depend on the kidney as a major route of $\mathbf{P}$ regulation, and so far it is not known with certainty whether $\mathbf{P}_{i}$ metabolism in ruminants is regulated primarily at the salivary glands or in the intestines.

Hormonal regulation of $\mathrm{Ca}$ and $\mathrm{P}$ homeostasis is characterized by common mechanisms and this is mainly achieved by three hormones, i.e. by parathyroid hormone (PTH), 
calcitonin and 1,25-(OH)$)_{2} \mathrm{D}_{3}$ (for reviews, see Neer, 1979; Drüeke \& Lacour, 1983; Horst, 1986; Reinhardt et al. 1988).

\section{CONTROL OF EPITHELIAL P $_{i}$ TRANSPORT}

It has been known for almost 60 years that both intestinal $\mathrm{Ca}$ and $\mathrm{P}_{\mathrm{i}}$ absorption can be stimulated by vitamin D (Harris \& Innes, 1931; Nicolaysen, 1937). The effect on $P_{i}$ absorption generally was assumed to be secondary to the improved $\mathrm{Ca}$ absorption since in in vitro studies on everted intestinal loops from rats and chicks removal of $\mathrm{Ca}$ from the system eliminated the vitamin $D$ effect on $P_{i}$ transport (Harrison \& Harrison, 1961; Morgan, 1969). In contrast to these findings Kowarski \& Schachter (1969) have shown, with similar techniques, that vitamin $\mathrm{D}$ has a direct and $\mathrm{Ca}$-independent action on the $\mathrm{P}_{\mathrm{i}}$ transport system. When $\mathrm{Na}^{+}$was removed from the incubation medium $\mathrm{P}_{\mathrm{i}}$ transport was inhibited, with no effect on $\mathrm{Ca}$ transport, and from this finding individual transport systems were postulated for both electrolytes (Harrison \& Harrison, 1963). Additional evidence for independent transport processes was provided by clinical studies on vitamin D-deficient patients suffering from $\mathrm{P}_{\mathrm{i}}$ malabsorption with no difference when $\mathrm{Ca}$ was either present or absent (Caniggia et al. 1968; Nordin, 1973). When these patients were treated with vitamin $D$, effects on $P_{i}$ transport could be detected earlier than for Ca (Stamp, 1972). More detailed information about the regulation of intestinal $P_{i}$ and $C a$ transport by vitamin $D$ was obtained by applying in vitro ion-flux measurements in Ussing chambers (Ussing \& Zerahn, 1951) and by uptake studies in BBMV (Schultz et al. 1967).

With both methods it was confirmed that $1,25-(\mathrm{OH})_{2} \mathrm{D}_{3}$ stimulates active $\mathrm{Ca}$ and $\mathrm{P}_{\mathrm{j}}$ transport independently (Danisi \& Straub, 1980; Lee et al. 1980; Murer \& Hildmann, 1981; Hildmann et al. 1982; Karsenty et al. 1985a; Jungbluth \& Binswanger, 1989) and that it involves both the classical steroid-receptor-mediated 'slow' genomic effects and 'fast ' nongenomic effects (Karsenty et al. 1985 b; Brasitus et al. 1986; De Boland \& Norman, 1990). Whereas the genomic effects primarily consist of the induction of intracellular Ca-bindingproteins the short-term effects are believed to involve changes in membrane fluidity in response to $1,25-(\mathrm{OH})_{2} \mathrm{D}_{3}$ (Rasmussen et al. 1979). Additionally it could be demonstrated that $1,25-(\mathrm{OH})_{2} \mathrm{D}_{3}$ can also stimulate the paracellular diffusional ion movement at least from the serosal to the mucosal side (Jungbluth \& Binswanger, 1989).

Studies on the role of the other important calciotropic hormones PTH and calcitonin have revealed contradictory results with respect to direct effects on $\mathrm{Ca}$ and $\mathrm{P}_{\mathrm{j}}$ transport (for review, see Drüeke \& Lacour, 1983; Lee et al. 1986 b, 1990; Cross et al. 1990) and it was suggested that the effects of both hormones may reflect indirect actions. Since PTH and calcitonin are more important in renal and bone $\mathrm{Ca}-\mathrm{P}_{\mathbf{i}}$ handling, their potential role in regulating intestinal transport will not further be discussed in the present paper.

It should be noted, however, that at least two other hormones might be involved in regulation of intestinal $\mathrm{P}_{\mathrm{i}}$ absorption. The full expression of the vitamin-D-dependent $\mathrm{Na}^{+}-$ coupled $\mathrm{P}_{\mathbf{i}}$ transport system in immature chick enterocytes required insulin (Peterlik et al. 1981) and the maximal stimulation of $\mathrm{P}_{i}$ transport could be achieved when embryonic jejunum was cultured in presence of both $1,25-(\mathrm{OH})_{2} \mathrm{D}_{3}$ and triiodothyronine (Cross et al. 1986; Cross \& Peterlik, 1988).

\section{INTERACTIONS BETWEEN P AND Ca HOMEOSTASIS}

Regulation of plasma levels of $1,25-(\mathrm{OH})_{2} \mathrm{D}_{3}$ depends on both plasma $\mathrm{P}_{\mathrm{i}}$ and $\mathrm{Ca}$ concentrations (Audran \& Kumar, 1985). In ruminants and non-ruminants the regulatory effects of $\mathrm{Ca}$ on plasma $1,25-(\mathrm{OH})_{2} \mathrm{D}_{3}$ are mediated by PTH which has been shown to 


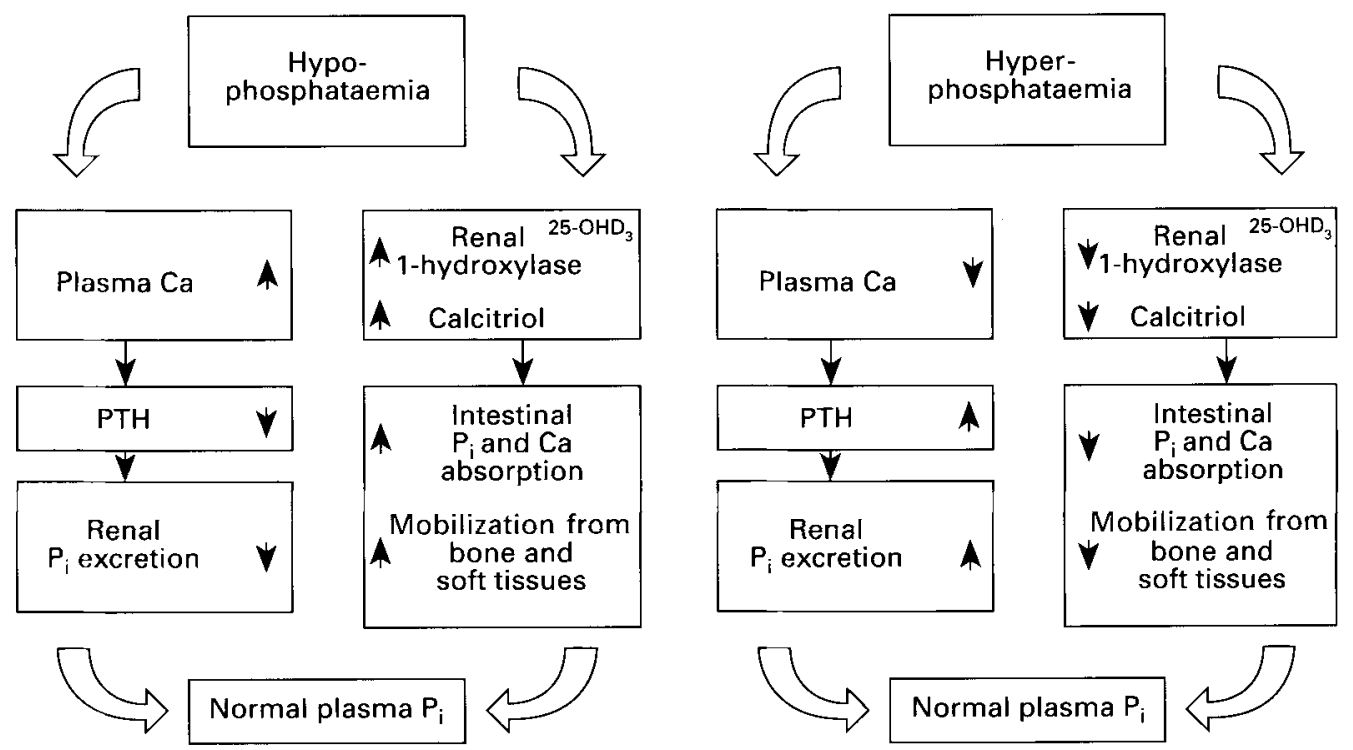

Fig. 1. Adaptational processes to hypo- and hyperphosphataemia. $\mathrm{P}_{\mathrm{i}}$, inorganic phosphate; $25-\mathrm{OHD}_{3}$ 1-hydroxylase, 25-hydroxycholecalciferol-1-hydroxylase $\quad(E C \quad 1.14 .13 .13)$; calcitriol, 1,25dihydroxycholecalciferol; PTH, parathyroid hormone.

stimulate the activity of renal 25-hydroxycholecalciferol-1-hydroxylase $(E C$ 1.14.13.13; 25-OHD 3 1-hydroxylase; Bilezikian et al. 1978; Korkor et al. 1985; Reinhardt et al. 1988). There is also evidence for direct regulation of this enzyme by Ca (Favus \& Langman, 1986). Stimulation of $25-\mathrm{OHD}_{3} 1$-hydroxylase by low serum $\mathrm{P}_{\mathrm{i}}$ has only been demonstrated in non-ruminants and this obviously does not depend on the presence of PTH (Tanaka \& DeLuca, 1973; Fox et al. 1978; Gray et al. 1983). The effects of low serum $P_{i}$ on renal 25$\mathrm{OHD}_{3}$ 1-hydroxylase may be mediated by somatomedins (Gray, 1987).

In ruminants hypophosphataemia is neither associated with any significant changes of plasma $1,25-(\mathrm{OH})_{2} \mathrm{D}_{3}$ concentrations nor with any changes of the metabolic clearance or production rate of this hormone, suggesting that adaptational processes to $\mathrm{P}$ depletion differ between ruminants and non-ruminants and that in ruminants no changes are involved at the vitamin D level (Breves et al. 1985; Maunder et al. 1986; Müschen et al. 1988; Schröder et al. 1990). However, it has been shown recently that, in lactating goats, $P$ depletion resulted in a significant increase in the intestinal $1,25-(\mathrm{OH})_{2} \mathrm{D}_{3}$ receptor binding affinity. It still has to be elucidated whether these changes are associated with any effects of intestinal $\mathrm{P}_{1}$ or Ca absorption (Schröder et al. 1990). Fig. 1 summarizes the major effects of either hypo- or hyperphosphataemia on adaptational processes in non-ruminant species.

In addition to the stimulatory effects of hypophosphataemia on intestinal $P_{i}$ absorption, hypercalcaemia develops which can be induced by increased intestinal $\mathrm{Ca}$ absorption and/or increased bone mobilization. Hypophosphataemia suppresses PTH secretion and, thus, minimizes urinary $P_{i}$ losses (Neer, 1979). In addition, intrinsic renal mechanisms may enhance tubular reabsorption and these mechanisms are not related to PTH or vitamin D (Audran \& Kumar,1985). The opposite sequence of events occurs in hyperphosphataemia. 


\section{DIETARY P DEFICIENCY IN RUMINANTS: EFFECTS ON MICROBIAL METABOLISM IN THE GASTROINTESTINAL TRACT}

Dietary $\mathbf{P}$ deficiency is one of the predominant mineral imbalances occurring in areas with extensive ruminant production systems. It may be accompanied by unspecific clinical or subclinical symptoms such as reduction in voluntary feed intake and decreases in growth and reproductive or lactational performance. In response to $\mathbf{P}$ depletion, disturbances in bone mineralization may also occur (Cohen, 1975; Field et al. 1975; Noller et al. 1977; Boxebeld et al. 1983; Smith, 1984).

Although reductions in feed intake have been found in many experimental studies the mechanisms by which they are induced are still unknown (Preston \& Pfander, 1964; Field et al. 1975; Bonilla, 1976; Boxebeld et al. 1983). The lowered nutrient supply, as induced by decreased feed intake, may be further amplified by reduced dry matter or organic matter (OM) digestibility (Farries \& Krasnodebska, 1972; Field et al. 1975; Sevilla \& Ternouth, $1980,1982)$ and from studies in sheep with duodenal and ileal cannulas it could be demonstrated that in absolute terms the rumen and the hind-gut took about equal shares in the reduction of OM digestion (Breves \& Höller, 1987a).

This agrees with comparative studies on microbial $P$ requirements when no differences between rumen and hind-gut microbes could be detected (Milton \& Ternouth, 1984). In order to ensure an undisturbed microbial metabolism in the rumen minimal $\mathbf{P}$ concentrations have to be in a range between 0.7 and $2.6 \mathrm{~mm}$ (Hall et al. 1961; Chicco et al. 1965; Durand et al. 1983; Milton \& Ternouth, 1984). Komisarczuk et al. (1987) have used a continuous rumen incubation system to determine effects on basic fermentative and synthetic processes of rumen microbes brought about by changes in rumen $P_{i}$ concentrations. By infusion of different buffer solutions $P_{i}$ concentrations were adjusted to between 1.5 and less than $0.03 \mathrm{~mm}$ within the rumen fluid. When the $P_{1}$ concentration was lowered to $0.1 \mathrm{~mm}$ cellulose digestion and volatile fatty acid (VFA) production decreased. Microbial protein synthesis was reduced at $P_{i}$ concentrations of less than $0.03 \mathrm{mM}$. These concentrations are significantly lower than those detected in the particle-free rumen fluid of P-depleted sheep, and were accompanied by significant decreases in OM digestibility in the rumen (Breves \& Höller, 1987a). The discrepancy between in vitro and in vivo results might have been induced by differences in adaptation times to low $\mathrm{P}_{\mathrm{j}}$ concentrations. In the in vivo experiments at least 3 weeks were allowed for adaptation to the low-P diet (Breves \& Holler, 1987a). Only a few in vivo experiments have been performed to study the effects of $\mathrm{P}$ depletion on gastrointestinal $\mathrm{N}$ metabolism. Decreases in $\mathrm{N}$ digestibility were found in sheep (Farries \& Krasnodebska, 1972) and the large intestines were the major site for this reduction (Breves \& Höller, 1987 b).

Whereas the nitrogen balance and the ammonia- $\mathrm{N}$ : non- $\mathrm{NH}_{3}-\mathrm{N}$ (NAN) ratio up to the end of the small intestines were not affected by the $\mathrm{P}$ status, significant effects of $\mathrm{P}$ depletion on kinetic variables of microbial growth could be demonstrated when ${ }^{15} \mathrm{NH}_{4} \mathrm{Cl}$ was used as a label for microbial protein synthesis. Net yield of microbial $\mathrm{N}$ was reduced by about $27 \%$; this decreased the microbial $\mathrm{N}$ pool in the rumen and correspondingly the flow of microbial $\mathrm{N}$ into the proximal duodenum (Lessmann, 1985; Breves \& Höller, $1987 \mathrm{~b}$ ). In P depletion the proportion of microbial $\mathrm{N}$ from the $\mathrm{NH}_{3}$ pool was lower and the flow of nonmicrobial NAN into the proximal duodenum was significantly higher. Both findings suggest that $\mathrm{P}$ depletion also reduced food protein degradation in the rumen. The efficiency of microbial growth was not affected. These studies were done in sheep which were kept close to maintenance levels. The depressive effects of $\mathbf{P}$ depletion on microbial metabolism could be confirmed qualitatively and were even more pronounced quantitatively in 
lactating goats. In these animals $\mathrm{P}$ depletion within the third month of lactation decreased the net yield of microbial $\mathrm{N}$ by about $60-65 \%$; hence the proportion of milk protein derived from microbial protein was lower (Petri et al. 1988).

The mechanisms by which growth depression is exerted have not yet been identified. Since the N:P ratio in microbial dry matter did not change (Breves, unpublished results) insufficient microbial synthesis of essential $\mathrm{P}$ compounds might limit microbial growth. Another explanation could be the fact that the method for determination of microbial growth measures net growth, i.e. the difference between gross growth and microbial lysis. Thus, the decreased flow of microbial $\mathrm{N}$ into the proximal duodenum might have been induced by an increased microbial lysis. There is no evidence that rumen protozoa are involved in changes of microbial growth. Within 3 weeks after the start of $\mathrm{P}$ depletion neither the individual species nor their concentrations changed significantly (Breves, unpublished results).

In conclusion, changes in microbial metabolism in P-depleted sheep and goats have to be considered as a major factor which reduces the endogenous supply of essential amino acids and, thus, is involved in reduced growth and reproductive or lactational performance. This may be amplified under free grazing conditions since $\mathrm{P}$ deficiency in plant material often coincides with $\mathbf{N}$ deficiency or with low-quality $\mathbf{N}$ compounds. Further studies should be carried out to elucidate whether dietary $\mathrm{P}$ depletion is also accompanied by changes in intermediary metabolism.

\section{CONCLUSIONS}

Secretory and absorptive processes for $\mathrm{P}_{\mathrm{i}}$ along the gastrointestinal tract are characterized by major differences between ruminant and non-ruminant species. The high salivary $P_{i}$ secretion in ruminants is well documented and, at least in sheep, the end-pieces of the parotid glands were found to be the major site for $P_{i}$ secretion. Little is known about the transport processes involved and how the uphill $P_{i}$ transport is regulated is still unknown.

Numerous experiments have been performed in single-stomach animals to identify epithelial $P_{i}$ transport in the small intestines and at least two mechanisms were found: (1) a passive non-saturable transport and (2) a secondary active $\mathrm{Na}^{+}$-coupled mechanism which is controlled by $1,25-(\mathrm{OH})_{2} \mathrm{D}_{3}$.

It is still unknown whether similar processes are present in the small intestines of ruminants. Recent findings suggest that in sheep $\mathrm{P}_{\mathrm{i}}$ uptake at the lumen side might be controlled by the $\mathrm{pH}$ gradient across the membrane. Although most of $\mathrm{P}_{i}$ is absorbed across the small intestinal wall, the rumen and omasum have been shown to be a potential site for net $\mathrm{P}_{\mathrm{i}}$ absorption, and from in vitro studies it was concluded that, in both organs, $\mathrm{P}_{\mathrm{i}}$ is absorbed by passive diffusion. In single-stomach animals hypophosphataemia enhances renal production of $1,25-(\mathrm{OH})_{2} \mathrm{D}_{3}$ and, thus, intestinal absorption of $\mathrm{Ca}$ and $\mathrm{P}_{1}$ which results in hypercalcaemia. In sheep and goats hypophosphataemia also induces hypercalcaemia without any effect on concentration or production rate of $1,25-(\mathrm{OH})_{2} \mathrm{D}_{3}$. Recent studies, however, have shown that goats at least adapt at the intestinal 1,25$(\mathrm{OH})_{2} \mathrm{D}_{3}$ receptor level, since in $\mathrm{P}$ depletion the affinity of these receptors significantly increased. The physiological significance of these changes is not yet understood.

Rumen microbial metabolism is affected by long-term dietary $\mathbf{P}$ depletion. When rumen $P$ concentrations are lower than $3 \mathrm{~mm} O M$ digestibility and microbial protein synthesis decrease significantly, and these changes may be of primary importance when P-deficient animals under free grazing conditions decrease milk production, growth or lactational performance. 
Thus, it may be speculated from the teleological point of view that ruminants have developed high salivary $\mathbf{P}_{\mathbf{i}}$ secretion in order to maintain rumen microbial metabolism as long as possible independent from dietary $\mathrm{P}$ supply.

\section{REFERENCES}

Audran, M. \& Kumar, R. (1985). The physiology and pathophysiology of vitamin D. Mayo Clinic Proceedings 60, $851-866$

Beardsworth, L. J., Beardsworth, P. M. \& Care, A. D. (1989). The effect of ruminal phosphate concentration on the absorption of calcium, phosphorus and magnesium from the reticulo-rumen of the sheep. British Journal of Nutrition 61, 715-723.

Ben-Ghedalia, D., Tagari, H. \& Geva, A. (1982). Absorption by sheep of calcium, phosphorus and magnesium from a poultry litter supplemented diet. Journal of Agricultural Science 98, 85-88.

Ben-Ghedalia, D., Tagari, H., Zamwel, S. \& Bondi, A. (1975). Solubility and net exchange of calcium, magnesium and phosphorus in digesta flowing along the gut of the sheep. British Journal of Nutrition 33, 87-94.

Berner, W., Kinne, R. \& Murer, H. (1976). Phosphate transport into brush-border membrane vesicles isolated from rat small intestine. Biochemical Journal 160, 467-474.

Bilezikian, J. P., Canfield, R. E., Jacobs, T. P., Polay, J. S., D'Adamo, A. P., Eisman, J. A. \& DeLuca, H. F. (1978). Response of 1 1 ,25-dihydroxyvitamin $\mathrm{D}_{3}$ to hypocalcemia in human subjects. New England Journal of Medicine 299, 437-441.

Bonilla, S. E. (1976). Phosphorus in the nutrition of sheep: composition of body fluids, microbial fermentation and feed intake. PhD Thesis, University of California, Davis.

Boxebeld, A., Guégen, L., Hannequart, G. \& Durand, M. (1983). Utilization of phosphorus and calcium and minimal maintenance requirement for phosphorus in growing sheep fed a low-phosphorus diet. Reproduction. Nutrition, Développement 23, 1043-1053.

Brasitus, T. A., Dudeja, P. K., Eby, B. \& Lau, K. (1986). Correction by 1,25-dihydroxycholecalciferol of the abnormal fluidity and lipid composition of enterocyte brush border membranes in vitamin D-deprived rats. Journal of Biological Chemistry 261, 16404-16409.

Breves, G., Gäbel, G., Martens, H. \& Höller, H. (1986). Phosphate fluxes across the rumen wall mucosa of sheep in vitro. Proceedings of the Nutrition Society 45, 99A.

Breves, G. \& Höller, H. (1987a). Effects of dietary phosphorus depletion in sheep on dry matter and organic matter digestibility. Journal of Animal Physiology and Animal Nutrition 58, 281-286.

Breves, G. \& Höller, H. (1987b). Gastrointestinal nitrogen turnover in sheep fed non-protein nitrogen and a phosphorus-deficient diet. In Isotope Aided Studies on Non-Protein-Nitrogen and Agroindustrial By-Products Utilization by Ruminants, pp. 19-29 [IAEA, editor]. Vienna: IAEA Publishing Series.

Breves, G., Höller, H., Packheiser, P., Gäbel, G. \& Martens, H. (1988). Flux of inorganic phosphate across the sheep rumen wall in vivo and in vitro. Quarterly Journal of Experimental Physiology 73, 343-351.

Breves, G., Rosenhagen, C. \& Höller, H. (1987). Die Sekretion von anorganischem Phosphor mit dem Speichel bei P-depletierten Schafen (Saliva secretion of inorganic phosphorus in phosphorus-depleted sheep). Journal of Veterinary Medicine A 34, 42-47.

Breves, G., Ross, R. \& Höller, H. (1985). Dietary phosphorus depletion in sheep: effects on plasma inorganic phosphorus, calcium, 1,25-(OH) - Vit- $\mathrm{D}_{3}$ and alkaline phosphatase and on gastrointestinal $\mathrm{P}$ and $\mathrm{Ca}$ balances Journal of Agricultural Science 105, 623-629.

Bruce, J., Goodall, E. D., Kay, R. N. B., Phillipson, A. T. \& Vowles, L. E. (1966/67). The flow of organic and inorganic materials through the alimentary tract of the sheep. Proceedings of the Royal Society B 166, 46-62.

Caniggia, A., Crennari, C., Bencini, M. \& Palazzonli, V. (1968). Intestinal absorption of ratio-phosphate in osteomalacia before and after vitamin D treatment. Calcified Tissue Research 2, 299-300.

Care, A. D., Barlet, J. P. \& Abdel-Hafeez, H. M. (1980). Calcium and phosphate homeostasis in ruminants and its relationship to the aetiology and prevention of parturient paresis. In Digestive Physiology and Metabolism in Ruminants, pp. 429-446 [Y. Ruckebusch and P. Thivend, editors]. Lancaster: MTP Press.

Caverzasio, J., Danisi, G., Straub, R. W., Murer, H. \& Bonjour, J. P. (1987). Adaption of phosphate transport to low phosphate diet in renal and intestinal brush border membrane vesicles; influence of sodium and $\mathrm{pH}$ Pflügers Archiv 409, 333-336.

Chicco, C. F., Ammerman, C. B., Moore, J. E., van Walleghem, P. A., Arrington, L. R. \& Shirley, R. L. (1965). Utilization of inorganic ortho-, meta- and pyrophosphates by lambs and by cellulolytic rumen microorganisms in vitro. Journal of Animal Science 24, 355-363.

Cohen, R. D. H. (1975). Phosphorus and the grazing ruminant. World Review of Animal Production 11 (2), 26-43.

Compton, J. S.. Nelson, J., Wright, R D. \& Young, J. A. (1980). A micropuncture investigation of electrolyte transport in the parotid glands of sodium-replete and sodium-depleted sheep. Journal of Physiology 309 , 429446.

Coroneo, M. T., Maier, H., Schindler, J. G. \& Heidland, A. (1981). The secretion of ionized and total calcium. protein and inorganic phosphate by the salivary glands of rat and man. In Saliva and Salivation, pp. 289-294 [T. Zelles, editor]. Oxford: Pergamon Press. 
Cramer, C. F. (1972). Aspects of intestinal absorption of $\mathrm{Ca}, \mathrm{P}$ and $\mathrm{Mg}$. Methods and progress. Methods and Achievements in Experimental Pathology 6, 172-192.

Cross, H. S., Debiec, H. \& Peterlik, M. (1990). Mechanism and regulation of intestinal phosphate absorption. Mineral and Electrolyte Metabolism 16, 115-124.

Cross, H. S. \& Peterlik, M. (1988). Cooperative effect of thyroid hormones and vitamin D on intestinal calcium and phosphate transport. In Cellular Calcium and Phosphate Transport in Health and Disease (Progress in Clinical and Biological Research 252), pp. 33 I-336 [F. Bronner and M. Peterlik, editors]. New York: Alan R. Liss, Inc.

Cross, H. S., Pölzleitner, D. \& Peterlik, M. (1986). Intestinal phosphate and calcium absorption: joint regulation by thyroid hormones and 1,25-dihydroxyvitamin $\mathrm{D}_{3}$. Acta Endocrinologica, Copenhagen 113, 96 -103.

Danisi, G., Bonjour, J. P. \& Straub, R. W. (1980). Regulation of the Na-dependent phosphate influx across the mucosal border of duodenum by 1,25-dihydroxycholecalciferol. Pflügers Archiv 388, 227-232.

Danisi, G., Caverzasio, J., Trechsel, U., Straub, R. \& Bonjour, J. P. (1988). Phosphate transport adaptation in intestinal brush border membrane vesicles (BBMV) and plasma levels of 1,25-dihydroxycholecalciferol. In Cellular Calcium and Phosphate Transport in Health and Disease (Progress in Clinical and Biological Research 252), pp. 65-66 [F. Bronner and M. Peterlik, editors]. New York: Alan R. Liss, Inc.

Danisi, G. \& Straub, R. W. (1980). Unidirectional influx of phosphate across the mucosal membrane of rabbit small intestine. Pfügers Archiv 385, 117-122.

Danisi, G., van Os, C. H. \& Straub, R. W. (1984). Phosphate transport across brush border and basolateral membrane vesicles of small intestine. In Epithelial Calcium and Phosphate Transport: Molecular and Cellular Aspects, pp. 229-234 [F. Bronner and M. Peterlik, editors]. New York: Alan R. Liss, Inc.

Debiec, H. \& Lorenc, R. (1988). Identification of $\mathrm{Na}^{+}-\mathrm{P}_{i}$-binding protein in kidney and intestinal brush-border membranes. Biochemical Journal 255, 185-19I.

De Boland, A. R. \& Norman, A. (1990). Evidence for involvement of protein kinase C and cyclic adenosine $3^{\prime}, 5^{\prime}$ monophosphate-dependent protein kinase in the 1,25-dihydroxyvitamin $\mathrm{D}_{3}$-mediated rapid stimulation of intestinal calcium transport, (transcaltachia). Endocrinology 127, 3945.

DeLuca, H. F. (1988). The vitamin D story: a collaborative effort of basic science and clinical medicine. $F A S E B$ Journal 2, 224-236.

Den Hartog, L. A., Huisman, J., Boer, H. \& Schaijk, G. H. A. (1985). The effect of various carbohydrate sources on the digestibility of minerals in the small and large intestine of pigs. Statens Husdyrbrugsforsøg 580, $203-206$.

Drochner, W. (1984). Einfluß wechselnder Rohfaser- und Pektingehalte im Futter auf einige praecaecale und postileale Verdauungsvorgänge beim wachsenden Schwein (Influence of various fibre and pectin contents in the diet of precaecal and postileal digestion in growing pigs). Fortschritte in der Tierphysiologie und Tierernährung 14, p. 125.

Drüeke, T. \& Lacour, B. (1983). Hormone regulation of intestinal calcium and phosphate transport. Effects of vitamin D, parathyroid hormone (PTH) and calcitonin (CT). In Intestinal Transport (Symposium 1982), pp. 249-257 [M. Gilles-Baillien and R. Gilles, editors]. Berlin, Heidelberg: Springer-Verlag.

Durand, M., Boxebeld, A., Dumay, C. \& Beaumatin, P. (1983). Influence of the level of dietary phosphorus on urea utilization by rumen microorganisms in lambs. In Protein Metabolism and Nutrition, vol. 2, pp. 263-266 [R. Pion, M. Arnal and D. Bonin, editors]. Paris: INRA.

Edrise, B. M. \& Smith, R. H. (1986). Exchanges of magnesium and phosphorus at different sites in the ruminant stomach. Archiv für Tierernährung 36, 1019-1027.

Engelhardt, W. von \& Hauffe, R. (1975). Funktionen des Blättermagens bei kleinen Hauswiederkäuern. IV. Resorption und Sekretion von Elektrolyten (Functions of the omasum in small domestic ruminants. IV. Absorption and secretion of electrolytes). Journal of Veterinary Medicine A 22, 363-375.

Farries, F. E. \& Krasnodebska, J. (1972). Untersuchungen über die Verwertung von Harnstoff bei Wiederkäuern. C. Einsatz halbsynthetischer Rationen. 8. Mitteilung: Zum Einfluß unterschiedlicher P-Versorgung (Utilisation of urea in ruminants. C. Use of semisynthetic diets. 8. Effect of different supplies of $\mathrm{P}$ on metabolism of $\mathrm{N}$ with feeds exclusively of NPN). Zeitschrift für Tierphysiologie, Tierernährung und Futtermittelkunde 30, 33-47.

Favus, M. J. (1985). Factors that infiuence absorption and secretion of calcium in the small intestine and colon. American Journal of Physiology 248, G147-G157.

Favus, M. J. \& Langman, C. B. (1986). Evidence for calcium-dependent control of 1,25-dihydroxyvitamin $\mathrm{D}_{3}$ production by rat kidney proximal tubules. Journal of Biological Chemistry 261, 11224-11229.

Field, A. C., Suttle, N. F. \& Nisbet, D. I. (1975). Effect of diets low in calcium and phosphorus on the development of growing lambs. Journal of Agricultural Science 85, 435-442.

Fox, J., Pickard, D. W., Care, A. D. \& Murray, T. M. (1978). Effect of low phosphorus diets on intestinal calcium absorption and the concentration of calcium-binding protein in intact and parathyroidectomized pigs. Journal of Endocrinology 78, 379-387.

Fuchs, R. \& Peterlik, M. (1979). Vitamin D-induced transepithelial phosphate and calcium transport by chick jejunum : effect of microfilamentous and microtubular inhibitors. FEBS Letters 100, 357-359.

Fuchs, R. \& Peterlik, M. (1980). Vitamin D-induced phosphate transport in intestinal brush border membrane vesicles. Biochemical and Biophysical Research Communications 93, 87--92.

Ghishan, F. K., Kikuchi, K. \& Arab, N. (1987). Phosphate transport by rat intestinal basolateral-membrane vesicles. Biochemical Joumal 243, 641-646. 
Grace, N. D. (1972). Studies on the movement of magnesium, calcium, phosphorus, sodium and potassium across the gut wall of sheep fed fresh pasture. Proceedings of the New Zealand Society of Animal Production 32, 77-84.

Grace, N. D., Ulyatt, M. J. \& Macrae, J. C. (1974). Quantitative digestion of fresh herbage by sheep. III. The movement of $\mathrm{Mg}, \mathrm{Ca}, \mathrm{P}, \mathrm{K}$ and $\mathrm{Na}$ in the digestive tract. Journal of Agricultural Science 82, 321-330.

Gray, R. W. (1987). Evidence that somatomedins mediate the effect of hypophosphatemia to increase serum 1,25dihydroxyvitamin $\mathrm{D}_{3}$ levels in rats. Endocrinology 121, 504-512.

Gray, R. W., Garthwaite, T. L. \& Phillips, L. S. (1983). Growth hormone and triiodothyronine permit an increase in plasma $1,25-(\mathrm{OH})_{2} \mathrm{D}$ concentrations in response to dietary phosphate deprivation in hypophysectomized rats. Calcified Tissue International 35, 100-106.

Greene, L. W., Webb, K. E. Jr \& Fontenot, J. P. (1983). Effect of potassium level on site of absorption of magnesium and other macro-elements in sheep. Journal of Animal Science 56, 1214-1221.

Guéguen, L., Besançon, P. \& Rérat, A. (1968). Utilisation digestive, cinétique de l'absorption et efficacité de la rétention du phosphore phytique chez le pore (Digestive utilization, kinetics of absorption and efficiency of retention of phytic phosphorus in pigs). Annales de Biologie Animale, Biochimie, Biophysique 8, 273-280.

Hall, O. G., Baxter, H. D. \& Hobbs, C. S. (1961). Effect of phosphorus in different chemical forms on in vitro cellulose digestion by rumen microorganisms. Journal of Animal Science 20, 817-819.

Harris, L. J. \& Innes, J. R. M. (1931). The mode of action of vitamin D. Studies on hypervitaminosis D. The influence of the calcium-phosphate intake. Biochemical Journal 25, 367-390.

Harrison, H. E. \& Harrison, H. C. (1961). Intestinal transport of phosphate: action of vitamin D, calcium, and potassium. American Journal of Physiology 201, 1007-1012.

Harrison, H. E. \& Harrison, H. C. (1963). Sodium, potassium and intestinal transport of glucose, L-tyrosine, phosphate and calcium. American Journal of Physiology 205, 107-111.

Hildmann, B., Storelli, C., Danisi, G. \& Murer, H. (1982). Regulation of $\mathrm{Na}^{+}-\mathrm{P}_{1}$ cotransport by 1,25dihydroxyvitamin $\mathrm{D}_{3}$ in rabbit duodenal brush border membrane. American Journal of Physiology 242, G533-G539.

Höller, H., Breves, G. \& Dubberke, M. (1988a). Flux of inorganic phosphate and calcium across the isolated mucosa of the sheep omasum. Journal of Veterinary Medicine A 35, 709-716.

Höller, H., Figge, A., Richter, J. \& Breves, G. (1988 b). Nettoresorption von Calcium und anorganischen Phosphat aus dem perfundierten Colon und Rectum von Schafen (Calcium and inorganic phosphate net absorption from the sheep colon and rectum perfused in vivo). Journal of Animal Physiology and Animal Nutrition 59, 9-15.

Horst, R. L. (1986). Regulation of calcium and phosphorus homeostasis in the dairy cow. Journal of Dairy Science 69, 604-616.

Jungbluth, H. \& Binswanger, U. (1989). Unidirectional duodenal and jejunal calcium and phosphorus transport in the rat: Effects of dietary phosphorus depletion, ethane-1-hydroxy-1,1-diphosphonate and 1,25dihydroxycholecalciferol. Research in Experimental Medicine 189, 439449.

Karsenty, G., Lacour, B., Ulmann, A., Piérandréi, E. \& Drüeke, T. (1985a). Phosphate fluxes in isolated enterocytes from vitamin D replete and vitamin D deficient rats - early effects of calcitriol. Pflügers Archiv 403, $151-155$.

Karsenty, G., Lacour, B., Ulmann, A., Piérandréi, E. \& Drüeke, T. (1985b). Early effects of vitamin D metabolites on phosphate fluxes in isolated rat enterocytes. American Journal of Physiology 248, G40-G45.

Kay, R. N. B. (1960). The rate of flow and composition of various salivary secretions in sheep and calves. Journal of Physiology 150, 515-537.

Kikuchi, K. \& Ghishan, F. K. (1987). Phosphate transport by basolateral plasma membranes of human small intestine. Gastroenterology 93, 106-113.

Komisarczuk, S., Merry, R. J. \& McAllan, A. B. (1987). Effect of different levels of phosphorus on rumen microbial fermentation and synthesis determined using a continuous culture technique. British Journal of Nutrition 57, 279-290.

Korkor, A. B., Gray, R. W. \& Henry, H. L. (1985). Evidence that cAMP mediates PTH stimulation of 25-OHvitamin $\mathrm{D}_{3}-1 \alpha$-hydroxylase activity in cultured mouse kidney cells. Kidney International 29, 162.

Kowarski, S. \& Schachter, D. (1969). Effects of vitamin D on phosphate transport and incorporation into mucosal constituents of rat intestinal mucosa. Journal of Biological Chemistry 244, 21 1-217.

Lee, D. B. N., Hardwick, L. L., Hu, M.-S. \& Jamgotchian, N. (1990). Vitamin D-independent regulation of calcium and phosphate absorption. Mineral and Electrolyte Metabolism 16, 167-173.

Lee, D. B. N., Walling, M. W. \& Corry, D. B. (1986a). Phosphate transport across rat jejunum : influence of sodium, $\mathrm{pH}$ and 1,25-dihydroxyvitamin $\mathrm{D}_{3}$. American Journal of Physiology 251, G90-G95.

Lee, D. B. N., Walling, M. W., Palant, C. E. \& Tallos, E. (1986b). Jejunal phosphate transport is not regulated by the PTH-adenylate cyclase system. Further studies on the contrasting features between intestinal and renal phosphate transport mechanisms. Mineral and Electrolyte Metabolism 12, 293-297.

Lee, D. B. N., Walling, M. W., Silis, V., Gafter, U. \& Coburn, J. W. (1980). Calcium and inorganic phosphate transport in rat colon. Dissociated response to 1,25-dihydroxyvitamin D3. Journal of Clinical Investigation 65 , 1326-1331.

Lessmann, H. W. (1985). Der Einfluß einer diätetischen Phosphordepletion auf den Nettozuwachs an mikrobiell gebundenem Stickstoff im Pansen von Schafen (Effects of dietary P-depletion on net microbial yield from the rumen of sheep). Thesis, School of Veterinary Medicine, Hanover. 
Luecke, H. \& Quiocho, F. A. (1990). High specificity of a phosphate transport protein determined by hydrogen bonds. Nature 347, 402-406.

McHardy, G. J. R. \& Parsons, D. S. (1956). The absorption of inorganic phosphate from the small intestine of the rat. Quarterly Journal of Experimental Physiology 41, 398-409.

Mañas-Almendros, M., Ross, R. \& Care, A. D. (1982). Factors affecting the secretion of phosphate in parotid saliva in the sheep and goat. Quarterly Journal of Experimental Physiology 67, 269-280.

Maunder, E. M. W., Pillay, A. V.\& Care, A. D. (1986). Hypophosphatemia and vitamin D metabolism in sheep. Quarterly Journal of Experimental Physiology 71, 391-399.

Milton, J. T. B. \& Ternouth, J. H. (1984). The effects of phosphorus upon in vitro microbial digestion. Animal Production in Australia 15, 472-475.

Morgan, D. B. (1969). Calcium and phosphorus transport across the intestine. In Malabsorption. Pfizer Medical Monographs no. 4, p. 74 [R. H. Girdwood and A. N. Smith, editors]. Baltimore: Williams \& Wilkins.

Mulroney, S. E. \& Haramati, A. (1990). Renal adaptation to changes in dietary phosphate during development. American Journal of Physiology 258, F1650-F1656.

Murer, H. \& Hildmann, B. (1981). Transcellular transport of calcium and inorganic phosphate in the small intestinal epithelium. American Journal of Physiology 240, G409-G416.

Müschen, H., Petri, A., Breves, G. \& Pfeffer, E. (1988). Response of lactating goats to low phosphorus intake. 1. Milk yield and faecal excretion of $\mathrm{P}$ and Ca. Journal of Agricultural Science 111, 255-263.

Neer, R. M. (1979). Calcium and inorganic-phosphate homeostasis. In Endocrinology, vol. 2, pp. 669-692 [L. J. DeGroot, G. F. Cahill Jr, L. Martini, D. H. Nelson, W. D. Odell, J. T. Potts Jr, E. Steinberger and A. 1. Winegrad, editors]. New York: Grune \& Stratton.

Nicolaysen, R. (1937). Studies upon the mode of action of vitamin D. III. The influence of vitamin D on absorption of calcium and phosphorus in the rat. Biochemical Journal 31, 122-129.

Nielsen, S. P. \& Petersen, O. H. (1970). Excretion of magnesium, calcium, and inorganic phosphate by the cat submandibular gland. Pflügers Archiv 318, 6367.

Noller, C. H., Castro, A. G., Wheeler, W. E., Hill, D. L. \& Moeller, N. J. (1977). Effect of phosphorus supplementation on growth rate, blood minerals, and conception rate of dairy heifers. Journal of Dairy Science 60, $1932-1940$.

Nordin, B. E. C. (1973). Metabolic Bone and Stone Disease. Edinburgh and London: Churchill Livingstone.

Parthasarathy, D. (1952). The absorption of certain elements from the alimentary tract of sheep. British Journal of Nutrition 6, V.

Parthasarathy, D. Garton, G. A. \& Phillipson, A. T. (1952). The passage of phosphorus across the rumen epithelium of sheep. Biochemical Journal 52, XVI-XVII.

Partridge, I. G., Simon, O. \& Bergner, H. (1986). The effects of treated straw meal on ileal and faecal digestibility of nutrients in pigs. Archiv für Tierernährung 36, 351-359.

Peerce, B. E. (1988). Identification and purification of the intestinal $\mathrm{Na}$ /phosphate cotransporter. In Cellular Calcium and Phosphate Transport in Health and Disease (Progress in Clinical and Biological Research 252), pp. 73-80 [F. Bronner and M. Peterlik, editors]. New York: Alan R. Liss, Inc.

Peerce, B. E. (1989). Identification of the intestinal Na-phosphorus cotransporter. American Journal of Physiology 256, G645-G652.

Peterlik, M., Fuchs, R. \& Cross, H. S. (1981). Phosphate transport in the intestine: cellular pathways and hormonal regulation. In Calcium and Phosphate Transport across Biomembranes, pp. 173-179 [F. Bronner and M. Peterlik, editors]. New York: Academic Press Inc.

Peterlik, M. \& Wasserman, R. H. (1978). Effect of vitamin D on transepithelial phosphate transport in chick intestine. American Journal of Physiology 234, E379-E388.

Petri, A., Müschen, H., Breves, G., Richter, O. \& Pfeffer, E. (1988). Response of lactating goats to low phosphorus intake. 2. Nitrogen transfer from rumen ammonia to rumen microbes and proportion of milk protein derived from microbial amino acids. Journal of Agricultural Science 111, 265-271.

Pfeffer, E. (1968). Untersuchungen über Mineralstoff-Bewegungen im Verdauungskanal von ausgewachsenen Hammeln. Habilitation Thesis, University of Göttingen.

Pfeffer, E., Thompson, A. \& Armstrong, D. G. (1970). Studies on intestinal digestion in the sheep. 3. Net movement of certain inorganic elements in the digestive tract on rations containing different proportions of hay and rolled barley. British Journal of Nutrition 24, 197-204.

Poppi, D. P. \& Ternouth, J. H. (1979). Secretion and absorption of phosphorus in the gastrointestinal tract of sheep fed on four diets. Australian Journal of Agricultural Research 30, 503-512.

Portale, A. A., Halloran, B. P. \& Morris, R. C. Jr (1989). Physiologic regulation of the serum concentration of 1,25-dihydroxyvitamin D by phosphorus in normal men. Journal of Clinical Investigation 83, 1494-1499.

Preston, R. L. \& Pfander, W. H. (1964). Phosphorus metabolism in lambs fed varying phosphorus intakes. Journal of Nutrition 83,369-378.

Quamme, G. A. (1985). Phosphate transport in intestinal brush-border membrane vesicles: effect of $\mathrm{pH}$ and dietary phosphate. American Journal of Physiology 249, G168-G176.

Radde, I. C., Davis, D., Sheepers, J. \& McKercher, H. G. (1980). Bidirectional transmucosal ${ }^{45} \mathrm{Ca}$ and ${ }^{32} \mathrm{P}$ fluxes across the small intestine of the young piglet: Relationship to intestinal $\mathrm{Ca}^{2+}-\mathrm{Mg}^{2}-\mathrm{ATPase}$ activity and postnatal age. In Pediatric Diseases Related to Calcium, pp. 153-163 [H. F. DeLuca and C. S. Anast, editors]. Oxford: Blackwell Scientific Publications. 
Rasmussen, H., Fontaine, O., Max, E. E. \& Goodman, D. B. P. (1979). The effect of $1 \alpha$-hydroxyvitamin D $_{3}$ administration on calcium transport in chick intestine brush border membrane vesicles. Journal of Biological Chemistry 254, 2993-2999.

Reinhardt, T. A., Horst, R. L. \& Goff, J. P. (1988). Calcium, phosphorus, and magnesium homeostasis in ruminants. Veterinary Clinics of North America: Food Animal Practice 4, 331-350.

Sacktor, B. \& Cheng, L. (1981). The effect of $\mathrm{pH}$ on the transport of phosphate by renal brush border membrane vesicles. In Calcium and Phosphate Transport across Biomembranes, pp. 117-122 [F. Bronner and M. Peterlik, editors]. New York: Academic Press, Inc.

Scarisbrick, R. \& Ewer, T. K. (1951). The absorption of inorganic phosphate from the rumen of the sheep. Biochemical Journal 49, LXXIX

Scharrer, E. (1985). Phosphate absorption at different intestinal sites in the developing lamb. Quarterly Journal of Experimental Physiology 70, 615-62I.

Schneider, K. M., Boston, R. C. \& Leaver, D. D. (1987). Quantitation of phosphorus excretion in sheep by compartmental analysis. American Journal of Physiology 52, R720-R731.

Schröder, B., Breves, G. \& Pfeffer, E. (1990). Binding propertics of duodenal 1,25-dihydroxyvitamin $\mathrm{D}_{3}$ receptors as affected by phosphorus depletion in lactating goats. Comparative Biochemistry and Physiology 96A, 495-498.

Schultz, S. G., Curran, P. F., Chez, R. A. \& Fuisz, R. E. (1967). Alanine and sodium fiuxes across mucosal border of rabbit ileum. Journal of General Physiology 50, 1241-1260.

Scott, D. (1988). Control of phosphorus balance in ruminants. In Aspects of Digestive Physiology in Ruminants, pp. 156-174 [A. Dobson and M. J. Dobson, editors]. Comstock Publishing Associates: Cornell University Press.

Scott, D. \& Beastall, G. (1978). The effects of intravenous phosphate loading on salivary phosphate secretion and plasma parathyroid hormone levels in the sheep. Quarterly Journal of Experimental Physiology 63, 147-156.

Scott, D., McLean, A. F. \& Buchan, W. (1984). The effect of variation in phosphorus intake on net intestinal phosphorus absorption, salivary phosphorus secretion and pathway of excretion in sheep fed roughage diets Quarterly Journal of Experimental Physiology 69, 439-452.

Sevilla, C. C. \& Ternouth, J. H. (1980). Effect of different dietary levels of calcium and phosphorus in sheep. Animal Production in Australia 13, 449.

Sevilla, C. C. \& Ternouth, J. H. (1982). Effects of calcium and phosphorus depletion and repletion in lambs Animal Production in Australia 14, 633

Sheikh, M. S., Schiller, L. R. \& Fordtran, J. S. (1990). In vivo intestinal absorption of calcium in humans. Mineral and Electrolyte Metabolism 16, 130-146.

Shirazi-Beechey, S. P., Beechey, R. B., Penny, J., Vayro, S., Buchan, W. \& Scott, D. (1991). Mechanisms of phosphate transport in sheep intestine and parotid gland: response to variation in dietary phosphate supply. Experimental Physiology 76, 231-241.

Shirazi-Beechey, S. P., Gorvel, J. P. \& Beechey, R. B. (1988). Intestinal phosphate transport: Localization, properties and identification, a progress report. In Cellular Calcium and Phosphate Transport in Health and Disease (Progress in Clinical and Biological Research 252), pp. 59-64 [F. Bronner and M. Peterlik, editors]. New York: Alan R. Liss, Inc.

Shirazi-Beechey, S. P., Kemp, R. B., Dyer, J. \& Beechey, R. B. (1989). Changes in the function of the intestinal brush border membrane during the development of the ruminant habit in lambs. Comparative Biochemistry and Physiology 94B, 801-806.

Sklan, D. \& Hurwitz, S. (1985). Movement and absorption of major minerals and water in ovine gastrointestinal tract. Journal of Dairy Science 68, 1659-1666.

Smith, A. H., Kleiber, M., Black, A. L. \& Baxter, C. F. (1955). Transfer of phosphate in the digestive tract. II Sheep. Journal of Nutrition 57, 507-527.

Smith, R. H. (1984). Minerals and rumen function. In Nuclear Techniques in Tropical Animal Diseases and Nutritional Disorders, pp. 79-96 [IAEA, editor]. Vienna: IAEA Publishing Series.

Stamp, T. C. B. (1972). The intestinal absorption of phosphorus. Its relation to calcium absorption and its treatment with vitamin $\mathrm{D}$ in osteomalacia, parathyroid dysfunction and chronic renal failure. Clinical Science 42, $16 \mathrm{P}$.

Tanaka, Y. \& DeLuca, H. F. (1973). The control of 25-hydroxyvitamin D metabolism by inorganic phosphorus. Archives of Biochemistry and Biophysics 154, 566-574.

Théwis, A. \& François, E. (1985). Intestinal absorption and secretion of total and lipid phosphorus in adult sheep fed chopped meadow hay. Reproduction, Nutrition, Développement 25, 389-397.

Ussing, H. H. \& Zerahn, K. (1951). Active transport of sodium as the source of electric current in the shortcircuited isolated frog skin. Acta Physiologica Scandinavica 23, 110-127.

Walling, M. W. (1977). Intestinal calcium and phosphate transport: differential responses to vitamin $\mathbf{I}_{3}$ metabolites. American Journal of Physiology 233, E488-E494.

Wasserman, R. H. (1988). Calcium and phosphate entry into cells: A brief overview. In Cellular Calcium and Phosphate Transport in Health and Disease (Progress in Clinical and Biological Research 252), pp. 3-13 [F. Bronner and M. Peterlik, editors]. New York: Alan R. Liss, Inc.

Wasserman, R. H. \& Taylor, A. N. (1976). Gastrointestinal absorption of calcium and phosphorus. In Handbook of Physiology, Section 7, Endocrinology, vol. 7, Parathyroid Gland, pp. 137-155 [G. D. Aurbach, editor] Washington, DC: American Physiology Society. 
Wilkinson, R. (1976). Absorption of calcium, phosphorus and magnesium. In Calcium, Phosphate and Magnesium Metabolism, pp. 36-112 [B. E. C. Nordin, editor]. New York: Churchill-Livingstone.

Wright, E. (1955). Site of phosphorus absorption in the sheep. Nature 176, 351-352.

Wright, R. D., Blair-West, J. R., Nelson, J. F. \& Tregear, G. W. (1984). Handling of phosphate by a parotid gland (ovine). American Journal of Physiology 246, F916-F926.

Wylie, M. J., Fontenot, J. P. \& Greene, L. W. (1985). Absorption of magnesium and other macro-minerals in sheep infused with potassium in different parts of the digestive tract. Journal of Animal Science 61, $1219-1229$.

Yano, F., Sekiya, M., Kawashima, R. \& Kumada, K. (1978). Transport of calcium, phosphorus and magnesium across the rumen wall. Japanese Journal of Zootechnical Science 49, 680-686.

Young, J. A. \& Schneyer, C. A. (1981). Composition of saliva in mammalia. Australian Journal of Experimental Biology and Medical Science 59, 1-53. 